\title{
A New Approach for Provenance Studies of Archaeological Finds: Inferences from Trace Elements in Carbonate Minerals of Alpine White Marbles by a Bench-to-Top $\mu$-XRF Spectrometer
}

\author{
Gloria Vaggelli, ${ }^{1}$ Margherita Serra, ${ }^{2}$ Roberto Cossio, ${ }^{2}$ and Alessandro Borghi ${ }^{2}$ \\ ${ }^{1}$ CNR-IGG Via Valperga Caluso, 35 I-10123 Torino, Italy \\ ${ }^{2}$ Dipartimento di Scienze della Terra, Via Valperga Caluso, 35 I-10123 Torino, Italy \\ Correspondence should be addressed to Gloria Vaggelli; vaggelli@igg.cnr.it
}

Received 4 October 2013; Accepted 15 December 2013; Published 6 February 2014

Academic Editor: Basilios Tsikouras

Copyright (C) 2014 Gloria Vaggelli et al. This is an open access article distributed under the Creative Commons Attribution License, which permits unrestricted use, distribution, and reproduction in any medium, provided the original work is properly cited.

\begin{abstract}
The metamorphic rocks outcropping in the Western Alps are characterised by a great variety of white marbles which have been used since the antiquity. This variety mostly includes nine historical Piedmont white marbles (Ornavasso, Candoglia, Crevola, Pont Canavese, Foresto, Chianocco, Prali, Brossasco, and Garessio marbles) coming from well-known quarry sites and belonging to different metamorphic geological units of the Western Alps. The petrographical, minerochemical, and C-O isotopic data of these white marbles have been integrated with $\mathrm{CaO}$ and trace element (Fe, Mn, and $\mathrm{Sr}$ ) concentration determined on single crystals of carbonate minerals (i.e., calcite and/or dolomite) by means of a bench-to-top $\mu$-XRF spectrometer. Principal component analysis and hierarchical cluster analysis were performed on a data set of 178 observations containing $\mathrm{CaO}, \mathrm{Fe}, \mathrm{Mn}$, and $\mathrm{Sr}$ concentration as well as the maximum grain size (MGS), $\delta^{18} \mathrm{O}$ and $\delta^{13} \mathrm{C}$. The use of only five selected variables $\left(\mathrm{CaO}, \mathrm{Fe}, \mathrm{Mn}, \mathrm{Sr}, \mathrm{and} \delta^{18} \mathrm{O}\right)$ has provided the correct allocation of each individual observation to its relevant class. Therefore, this approach based mostly on a noninvasive $\mu$-XRF determination will be useful to define the provenance of unknown marbles of alpine origin used in antiquity for cultural heritage.
\end{abstract}

Dedicated to the memory of Margherita Serra, unforgettable Ph.D. Student and friend who early left an indelible sign behind

her

\section{Introduction}

One of the most difficult problems that archaeometry has faced in recent decades is certainly the identification of white marbles used in antiquity. Determining the provenance of marbles used in antiquity for architectural and sculptural artefacts can, indeed, yield important archaeological information on their history. Up to nowadays, different methods have been developed to distinguish white marbles coming from different quarry districts [1]. The optimal first steps in sourcing a lithic artefact should be the macroscopic and thin section study with the petrographic microscope. Unfortunately, it is often the case that it is not allowed to take a sample which is suitable for thin section preparation from precious artefacts. Instead, a common procedure is to analyse powder samples in various ways. The system most widely used today is that of determining $\mathrm{C}-\mathrm{O}$ isotopic signatures [2-5]. However, with the rapidly growing of databank, the compositional fields in the isotope discriminative diagrams have been progressively expanded, so many classical marbles show relatively large overlapping ranges.

Other techniques employed for marble characterization are cathodoluminescence $[6,7]$, trace and rare earth element contents [8-10], electron paramagnetic/spin resonance [11], and ${ }^{87} \mathrm{Sr} /{ }^{86} \mathrm{Sr}$ isotopic ratios [12-14].

Chemical analyses were also attempted as a criterion for ascribing a marble to a specific source, and a large number of papers (see e.g., [15]) on this topic have been published 
following the first work by [16]. Multielement neutron activation analysis of various trace elements was applied to pinpoint the origins of marbles, and this method has been used successfully for characterizing marble quarries in different geographic areas [8, 17-19].

However, single provenance determinations using only one method are still insufficient because overlapping results within and between different sample regions occur. Therefore, a number of techniques have been combined to precisely determine the marble provenance $[6,10,21-27]$.

Aim of this paper is to present a new chemical approach to discriminate white marbles, in addition to the conventionally used methods based on petrography, cathodoluminescence, and stable isotope analysis, in order to ascribe their provenance to a specific quarry site or at least to a defined geological unit. Abandoning the idea of a traditional approach to bulk analysis, this paper aims to evaluate the effectiveness of a new methodological approach based on major and trace element characterization of carbonate mineral phases, calcite and dolomite, being the main rock-forming minerals of white marbles.

As $\mu$-XRF technique is a prominent system for the nondestructive and/or noninvasive analysis of trace elements in glasses [28] and in minerals occurring in ornamental stones from cultural heritage $[29,30]$, our attention has been focused on the provenance study of marbles used in antiquity by trace elements determination in the main carbonate mineral phase. Therefore, the multianalytical approach based on petrographic (optical and scanning electron microscope), electron microprobe, and stable isotope analysis on calcite and dolomite from white marbles occurring in Western Alps (Piedmont, Italy) reported by [20] has been integrated with trace elements analysis through $\mu$-XRF. This new analytical protocol was used to characterize and identify different marble varieties and understand the effective discriminative power of trace element patterns in carbonate mineral phases.

\section{Geological Setting of Alpine White Marbles}

The Western Alps of Northern Italy represent a segment of the Alpine-Himalayan orogenic chain associated with the closure of the Western Tethys ocean [31]. Morphologically they are the expression of the continental collision between the European and the Adriatic (African) plates. Many geological units of the Piedmont Western Alps (Northern Italy) have provided a great variety of white marbles (Figure 1) which can be grouped in two classes: the marbles belonging to the Pre-Triassic (Palaeozoic) crystalline basement of the Western Alps, characterised by polymetamorphic evolution and the Triassic marbles coming from the metasedimentary cover, with monometamorphic evolution. The Palaeozoic marbles include the Ornavasso marble (from Ivrea-Verbano zone in Ossola valley), the Prali and Brossasco marbles (from Dora Maira Massif), and the Pont Canavese marble (from Sesia Lanzo zone). The Triassic ones consist of Foresto and Chianocco marbles (from the metasedimentary cover of Dora Maira Massif), Crevola marble (from the deepest Penninic unit in Ossola valley), and finally the Garessio marble (from Briançonnais zone).
Less known than the more famous Apuan varieties (the well-known Carrara marbles), white marbles from western Alps (Piedmont region) have been widely used in the past for sculptural and architectural purposes [32]. Since Roman times to late Baroque, Piedmont region shows the signs of an intensive quarry activity, which results in renowned examples from the Augustus Arc in Susa to the Savoy architecture in Turin.

Besides the interest for provenance purposes, Piedmont Alpine white marbles provide also the opportunity to investigate variations in trace elements composition according to different pressure-temperature conditions and to combine the microchemical results with $\mathrm{C}-\mathrm{O}$ isotope data on the same marble. The main varieties, indeed, occur as small lenses intercalated to schists and gneisses belonging to separate geological units which suffered different metamorphic conditions (i.e., different $P-T$ genetic conditions) during different times.

\section{Samples and Experimental Techniques}

3.1. Sample Descriptions. This work has been carried out on white marbles collected in 9 different quarries located in Piedmont Western Alps. Approximate geographical locations of the quarries are given in Figure 1.

The studied marbles come from the private collection of DST-UNITO and were previously studied by [20]. A list of the selected samples corresponding to alpine marble types, commercially known, is reported on Table 1 together with their main petrographic features, $\mathrm{C}-\mathrm{O}$ isotope data, and metamorphic conditions.

The studied alpine marbles were classified according to the main carbonate component, calcite $\left(\mathrm{CaCO}_{3}\right)$ or dolomite $\left[\mathrm{CaMg}\left(\mathrm{CO}_{3}\right)_{2}\right]$. The calcitic marbles, are characterized by a maximum $20 \%$ dolomite to calcite ratio and correspond to Brossasco, Garessio, Ornavasso, and Candoglia marbles. Marble from Prali, in Dora Maira massif, is mainly calcitic, with a dolomite content up to $50 \%$, and therefore both carbonate phases are almost equally abundant. Finally, over $50 \%$ dolomite concentration characterizes Pont Canavese, Foresto, and Chianocco marbles as well as Crevola marble which presents two varieties of commercial interest, showing different mineropetrographic features, though they are exploited in the same quarry site [20].

3.2. Instrumentation. Micro-XRF Eagle III-XPL (Röntgenanalytik Messtechnik GmbH, Germany) was used for trace elements analysis of calcite and dolomite in rock samples.

The system includes a Rh X-ray tube working at a maximum voltage of $50 \mathrm{kV}$ and a maximum current of $1 \mathrm{~mA}$. The $\mathrm{X}$-ray fluorescence is detected by means of a liquid nitrogen cooled ultrapure $\mathrm{Si}$ detector which has an active area of $30 \mathrm{~mm}^{2}$ and $5 \mu \mathrm{m}$ beryllium window. The energy resolution results to be lower than $135 \mathrm{eV}$. Polycapillary lenses collimate X-ray microbeam at the sample surface $(30 \mu \mathrm{m})$. The sample positioning is controlled by a two CCD video cameras, respectively, with a $10 \mathrm{x}$ and $100 \mathrm{x}$ magnification and optical focusing. The X-Y-Z stage minimum step is $1.5 \mu \mathrm{m}$. 


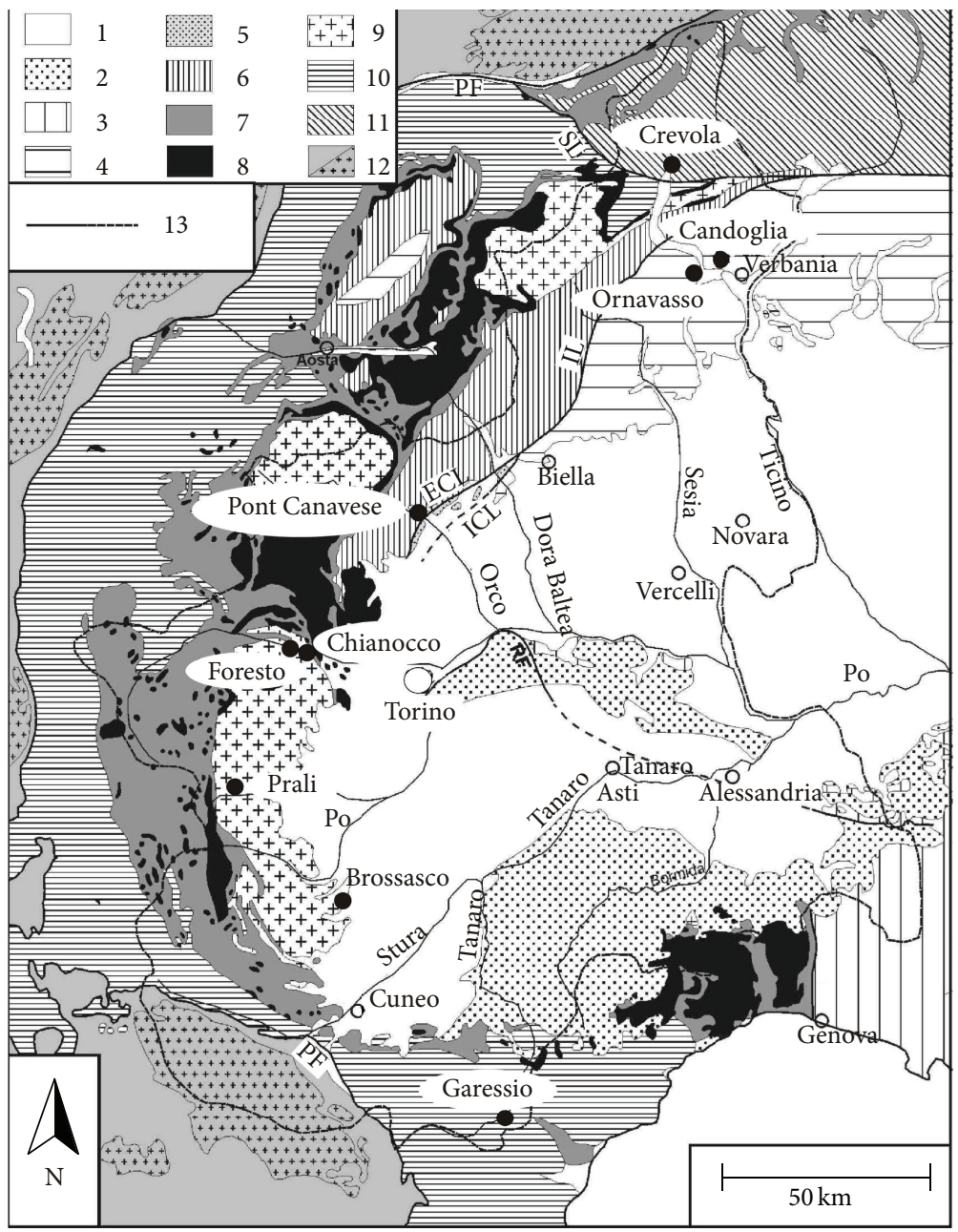

Figure 1: Tectonic sketch map of the Western Alps. The locations of the historical quarries are reported. Modified after [20]. Legend: $1=$ Postorogenic continental and marine terrigenous deposits of Plio-Pleistocene to Quaternary age. 2 = late orogeny fore-deep turbiditic deposits of Oligo-Miocene age. 3 = Apennine chain. $4=$ South-Alpine domain. $5=$ Canavese zone. $6=$ Austroalpine domain. $7-11=$ Penninic domain: 7 = upper Piedmont unit; $8=$ lower Piedmont unit; $9=$ internal crystalline massifs; $10=$ Briançonnais zone; $11=$ lower penninic unit. $12=$ Helvetic domain. 13 = tectonic lines: $\mathrm{PF}=$ Penninic front; $\mathrm{SL}=$ Simplon line; $\mathrm{ECL}=$ external Canavese line; $\mathrm{ICL}=$ internal Canavese line; $\mathrm{IL}=$ insubric line; $\mathrm{RF}=$ Rio Freddo line.

TABLE 1: List of studied alpine marbles: type, microscopic features, and C-O isotope from [20].

\begin{tabular}{|c|c|c|c|c|c|c|c|}
\hline $\begin{array}{l}\text { Piedmont alpine } \\
\text { marbles }\end{array}$ & $\begin{array}{c}\text { Main carbonate } \\
\text { mineral phase }\end{array}$ & $\begin{array}{l}\text { Acronyms used in } \\
\text { text and figures }\end{array}$ & $\begin{array}{c}\text { Metamorphic } \\
\text { conditions }\end{array}$ & $\begin{array}{c}\delta^{18} \mathrm{O} \\
\left(\delta \%_{0}\right)\end{array}$ & $\begin{array}{c}\delta^{13} \mathrm{C} \\
\left(\delta \%_{0}\right) \\
\end{array}$ & $\begin{array}{c}\text { AGS } \\
(\mathrm{mm})\end{array}$ & $\begin{array}{l}\text { MGS } \\
(\mathrm{mm})\end{array}$ \\
\hline Brossasco & Calcite & BRO-C & HP Eclogite & -7.3 & 0.7 & 0.7 & 3.7 \\
\hline Garessio & Calcite & GAR-C & Green Schists & -1.5 & 2.8 & 0.09 & 0.65 \\
\hline Ornavasso & Calcite & ORN-C & Granulite & -12.3 & 1.1 & 1.0 & 5.7 \\
\hline Candoglia & Calcite & CAN-C & Granulite & $-12.2^{*}$ & $1.3^{*}$ & - & - \\
\hline Crevola (2 varieties) & Dolomite & CRE-D1/ CRE-D2 & Amphibolite & $-3.0 /-5.3$ & $1.4 / 2.0$ & $0.14 / 0.32$ & 0.9 \\
\hline Pont Canavese & Dolomite & PONT-D & Eclogite & -7.3 & 1.4 & 0.26 & 0.8 \\
\hline Foresto & Dolomite & FOR-D & Eclogite & -4.3 & 1.2 & 0.15 & 0.6 \\
\hline Chianocco & Dolomite & CHI-D & Eclogite & -4.7 & 1.2 & 0.07 & 0.5 \\
\hline Prali & Calcite/dolomite & PRA-C/PRA-D & Eclogite & $-7.4 /-7.1$ & $1.5 / 1.7$ & 0.19 & 0.8 \\
\hline
\end{tabular}

AGS and MGS terminology according to $[4,39,40]$.

$\delta^{13} \mathrm{C}$ and $\delta^{18} \mathrm{O}$ data are expressed versus PDB standard [41].

Analytical protocol according to [42]. Standard deviation: $0.1\left(\delta \%_{0}\right)$ for $\delta^{18} \mathrm{O}$ and for $\delta^{13} \mathrm{C}$.

${ }^{*}$ Data from [43]. In acronyms: C: calcite; D: dolomite. 
The instrument can work both in air or in vacuum and data can be acquired selecting single spot, line-scan, or element mapping scan mode.

Peak to background ratio can be optimized in the energetic range of interest with a set of different primary filters and accordingly adjusting analytical conditions. Available primary filters correspond to Al-25 $\mu \mathrm{m}, \mathrm{Al}-250 \mu \mathrm{m}, \mathrm{Ti}-25 \mu \mathrm{m}$, $\mathrm{Ni}-25 \mu \mathrm{m}, \mathrm{Nb}-35 \mu \mathrm{m}$, and Rh-50 $\mu \mathrm{m}$ thickness. Filtering the primary radiation is one of the most effective methods to reduce the importance of diffraction peaks in the spectra as well as to drastically reduce the counts of lighter elements and to increase the peak/background ratio for heavier elements. It is, therefore, clear that the selection of proper primary filters must be a compromise between the optimization of peak to background ratio in the energetic range of interest and the minimization of coherent scattering phenomena. The Ti-25 filter was found proper for the quantification of trace elements in the energetic range of transition metals up to $\mathrm{Nb}$ to minimize the intensity of diffraction lines and accordingly avoid drastic reduction of total count rates with heavier filters.

In addition to Ti-filtering, the final spectra were obtained combining five spectra acquired on the same spot areas after rotation along a vertical axis located in the centre of the analysed area.

The object of rotating the sample in its analysis plane was to identify and remove artifact lines from the characteristic spectra. A specific facility called Del Diff-Peaks in Spc Preview routine of Vision32 software was used for this purpose and the final X-ray spectra result from 5 rotations after removal of peaks whose position change with the angle between the incoming radiation and the sample crystalline lattice. Sample rotation angles were defined as separated by $72^{\circ}$ because 5-fold symmetry (360/5) does not exist in Earth minerals: this means that the $0^{\circ}, 72^{\circ}, 140^{\circ}, 212^{\circ}$, and $288^{\circ}$ rotations were chosen. The subtraction of the diffraction contribution, channel by channel, occurs when the component spectra (rotated by $72^{\circ}$ ) differ by more than 5 times $\sigma$ : in this case the final spectrum takes the minimum value (i.e., the minimum diffraction contribution) or the average value (i.e., in absence of diffraction).

3.3. Analytical Conditions. Analyses were performed on big samples cut into $4 \times 4 \times 2 \mathrm{~cm}$ flat blocks in order to test the chemical composition homogeneity of calcite. However, the minimum size of the sample, which is connected to the lateral and depth resolution of the method, can be approximately $100 \times 100 \times 300 \mu \mathrm{m}$. In regard to the maximum size, an object of approximately $150 \times 150 \times 70 \mathrm{~mm}$ can be logged entirely inside the sample chamber. Finally, because the lateral resolution of the X-ray beam is $\approx 30 \mu \mathrm{m}$, the flatness of the surface affects the result very little but the surface (i.e., the spot area to be analysed) has to be clean; indeed, dirt or patinas could contain the same elements as the sample and possibly invalidate the final quantification.

In addition to $\mathrm{C}$ and $\mathrm{O}$ which form the carbonate ion, undetectable by micro-XRF, $\mathrm{Ca}$ is the major element for calcite and $\mathrm{Ca}$ and $\mathrm{Mg}$ for dolomite, respectively. The analytical method proposed for the measurements of trace elements in carbonate phase does not allow measuring $\mathrm{Mg}$. Indeed the use of a Ti-filter drastically reduces the X-ray counts and in particular light elements with $10<Z<16$ become more or less undetectable. However, the $\mathrm{MgO} / \mathrm{CaO}$ ratio is mostly constant in dolomite, and therefore the only quantification of $\mathrm{CaO}$ is able to easily distinguish between dolomite and calcite crystals (some 31 and 56 wt.\%, resp.). In regard to trace elements, only $\mathrm{Fe}, \mathrm{Mn}$, and $\mathrm{Sr}$ were the detected elements, which, moreover, correspond to the most abundant and common trace elements occurring in carbonate minerals.

The analytical conditions used for determining $\mathrm{CaO}$ and trace elements ( $\mathrm{Mn}, \mathrm{Fe}$, and $\mathrm{Sr}$ ) in calcite and dolomite include the following instrumental parameters: voltage, $40 \mathrm{kV}$; beam current, $1000 \mu \mathrm{A}$ live time, $1000 \mathrm{~s}$. In addition, a titanium primary filter ( $25 \mu \mathrm{m}$ in thickness) was inserted between anode and samples. All analyses were carried out in vacuum conditions even if the vacuum is indispensable only for the detection of light elements $(Z<15)$. The final composition was quantified adopting the intensity method proposed by [33] using an internal working standard of either calcite (M43) or dolomite (Dolo22), as a result of the identical matrices with respect to calcite and dolomite in the studied samples.

The used calcite working standard is from M43 Carrara marble, internationally used as standard for $\mathrm{C}$ and $\mathrm{O}$ isotope. It was, first, measured by ICP-OES and ICP-MS techniques, according to $\mathrm{HCl} 5 \%$ bulk rock dissolution method $(\mathrm{CaO}=$ 56 wt. $\%, \mathrm{Sr}=157 \mathrm{ppm}, \mathrm{Fe}=64 \mathrm{ppm}$, and $\mathrm{Mn}=10 \mathrm{ppm})$ and finally by multiple $\mu$-XRF tests to check the homogeneity of the calcite grains. M43 calcite was then used to quantify the dolomite working standard (Dolo22 from the standards library of the SPI Supplies and the C. M. Taylor Company) using Fp-with standard method according to [28].

\section{Data Treatment}

All selected samples (i.e., alpine marble types) are of known provenance; therefore, in this work, we are trying to verify the reliability of the proposed method to discriminate between white marbles using chemical information corroborated by a geomineralogical approach. In the studied marbles, the MGS (and subordinately AGS) as well as the $\delta^{18} \mathrm{O}$ and $\delta^{13} \mathrm{C}$ values resulted in the more variable petrographic parameters, and therefore useful for discriminative purposes according to a multivariate analysis approach in addition to the chemical major and trace composition of the main carbonate phase (calcite or dolomite). The recourse to a multivariate statistical treatment of the available data to obtain a classification of samples in groups of common provenance has long been known in the field of archaeometry [8, 34-36].

The parameter determined on the analyzed carbonate crystals $\left(\mathrm{CaO}, \mathrm{Fe}, \mathrm{Mn}\right.$, and $\mathrm{Sr}$ concentration, MGS, $\delta^{18} \mathrm{O}$ and $\delta^{13} \mathrm{C}$ ) was used to perform an unsupervised pattern recognition and to identify groups of marbles sharing a possible common provenance. This process was carried out running principal component analyses (PCA) and hierarchical agglomerative cluster analysis (HCA) by means 
TABLE 2: Measured $\mu$-XRF elements: mean and standard deviation $(\sigma)$ values are calculated from a variable number of diffraction free spectra reported in \# points column.

\begin{tabular}{|c|c|c|c|c|c|c|c|c|c|}
\hline & \multicolumn{2}{|c|}{$\mathrm{CaO}(\mathrm{wt} \%)$} & \multicolumn{2}{|c|}{$\mathrm{Fe}(\mathrm{ppm})$} & \multicolumn{2}{|c|}{$\mathrm{Sr}(\mathrm{ppm})$} & \multicolumn{2}{|c|}{$\mathrm{Mn}(\mathrm{ppm})$} & \multirow{2}{*}{ \# points } \\
\hline & Mean & $\sigma$ & Mean & $\sigma$ & Mean & $\sigma$ & Mean & $\sigma$ & \\
\hline BRO-C & 55.67 & 1.30 & 454 & 20 & 107 & 4 & 27 & 4 & 11 \\
\hline GAR-C & 56.71 & 1.69 & 137 & 40 & 145 & 13 & 33 & 11 & 23 \\
\hline ORN-C & 55.51 & 0.70 & 199 & 6 & 172 & 19 & 236 & 3 & 12 \\
\hline CAN-C & 56.70 & 0.85 & 239 & 3 & 200 & 35 & 170 & 3 & 12 \\
\hline CRE-D1 & 30.66 & 0.48 & 164 & 9 & 86 & 26 & 64 & 3 & 25 \\
\hline CRE-D2 & 31.36 & 1.83 & 325 & 11 & 90 & 10 & 65 & 3 & 11 \\
\hline PONT-D & 31.27 & 0.61 & 54 & 16 & 1095 & 71 & 15 & 2 & 19 \\
\hline FOR-D & 30.23 & 1.38 & 199 & 24 & 143 & 16 & 16 & 1 & 25 \\
\hline CHIA-D & 30.69 & 1.80 & 54 & 14 & 143 & 16 & 29 & 2 & 15 \\
\hline PRA-C & 54.97 & 1.32 & 168 & 15 & 534 & 46 & 10 & 1 & 15 \\
\hline PRA-D & 31.39 & 1.32 & 87 & 7 & 130 & 25 & 13 & 1 & 10 \\
\hline & & & & & & & & Total & 178 \\
\hline
\end{tabular}

Total \# points $=$ 178. C: calcite; D: dolomite.

of OriginPro 8.6.0 package (2011-OriginLab Corporation: http://www.OriginLab.com/). As the variables are measured on different scales $(\mathrm{CaO}$ wt $\%$ range, $\mathrm{Mn}, \mathrm{Fe}, \mathrm{Sr} \mathrm{ppm}$ range, $\delta^{18} \mathrm{O}$, and $\delta^{13} \mathrm{C} \delta \%_{o}$ range), the correlation matrix S (covariance matrix weighted by the standard deviation of variable) was used to process the data and to calculate the Eigenvalues and eigenvectors parameters. In this way, scores for each principal component are scaled by the square root of its eigenvalue.

HCA was performed using the squared "Euclidean distance" (geometric distance in multidimensional space) function, where the greater emphasis to objects that are further apart is stressed. The "group average" option was also used, that is, the distance between two clusters calculated as the average distance between all pairs of objects in different clusters.

\section{Results and Discussions}

5.1. Trace Elements in Calcite and Dolomite. According to the main carbonate phase of each alpine white marble, calcite or dolomite phases were analysed for major and trace element determination. In particular, calcite was analysed in Ornavasso $(\mathrm{ORN}-\mathrm{C})$ and Candoglia $(\mathrm{CAN}-\mathrm{C})$ as well as in Brossasco (BRO-C) and Garessio (GAR-C) marbles, dolomite in Pont Canavese (PONT-D), Foresto (FOR-D), and Chianocco (CHI-D) marbles and in both Crevola varieties (CRED1; CRE-D2) while calcite and dolomite, occurring in almost the same amounts, were analysed in Prali marble (PRA-C and PRA-D, resp.).

Our set of measurements included, on the whole, $178 \mu$ XRF spectra, diffraction subtracted, measured on nine different alpine white marbles, using the method described above: Ca was expressed as wt $\%$ oxide $(\mathrm{CaO}), \mathrm{Mn}, \mathrm{Fe}$, and $\mathrm{Sr}$ as ppm element (part per million by weight). It has to be pointed out that Crevola marble is represented by two classes corresponding to two varieties (CRE-D1 and CRE-D2) as well as Prali marble, which contains similar amounts of calcite and dolomite which were both analyzed (PRA-C and PRA$D)$; therefore, the nine marble types are represented by eleven classes.

In Table 2 mean and standard deviation values are reported for each $\mu$-XRF measured element; these quantities are calculated, for any class, from the number of observations reported in "\# points" column: this number ranges from a minimum of 10 in dolomite of Prali (PRA-D) to a maximum of 25 in calcite of Foresto marble (FOR-D) and corresponds to the number of analyzed carbonate crystals. The $\mathrm{CaO}$ values, since the standard deviation is low, are very close to theoretical values for calcite (some $56.00 \mathrm{wt} \%$ ) and dolomite (some $31.00 \mathrm{wt} \%$ ), respectively.

Figure 2 shows two scatter plots using $\mathrm{Fe}$ (ppm) as common abscissa versus Sr (Figure 2(a)) and Mn (Figure 2(b)), respectively. $\mathrm{Sr}$ concentration is below $200 \mathrm{ppm}$, except for PRA-C and PONT-D where it increases up to a mean value of $534 \pm 46$ and $1095 \pm 71 \mathrm{ppm}$ values, respectively. $\mathrm{Mn}$ concentration is generally very low (below $70 \mathrm{ppm}$ ), except for CAN-C and ORN-C samples where it reaches a mean value of $170 \pm 3$ and $236 \pm 3 \mathrm{ppm}$, respectively. In regard to $\mathrm{Fe}$, it seems the most variable trace element ranging from about $50 \mathrm{ppm}$ in PONT-D and CHI-D marbles to almost $500 \mathrm{ppm}$ in BRO-C marble, respectively.

All the marbles analyzed show compositional zoning rather limited compared to the three trace elements measured. This means that the dispersion of trace elements within the crystal lattice of carbonate minerals is homogeneous and that the method proposed in this work can be worthwhile for discriminating between marbles of different origin.

In Prali marble, the analysis of coexisting and cogenetic calcite and dolomite shows that higher contents of $\mathrm{Sr}$ and $\mathrm{Fe}$ occur in $\mathrm{CaCO}_{3}$ mineral phase, suggesting the higher distribution coefficient of $\mathrm{Sr}$ and $\mathrm{Fe}$ in calcite than in dolomite as also supported by previous authors studying the temperature dependence of the distribution coefficient of strontium in calcite and dolomite [37, 38]. 


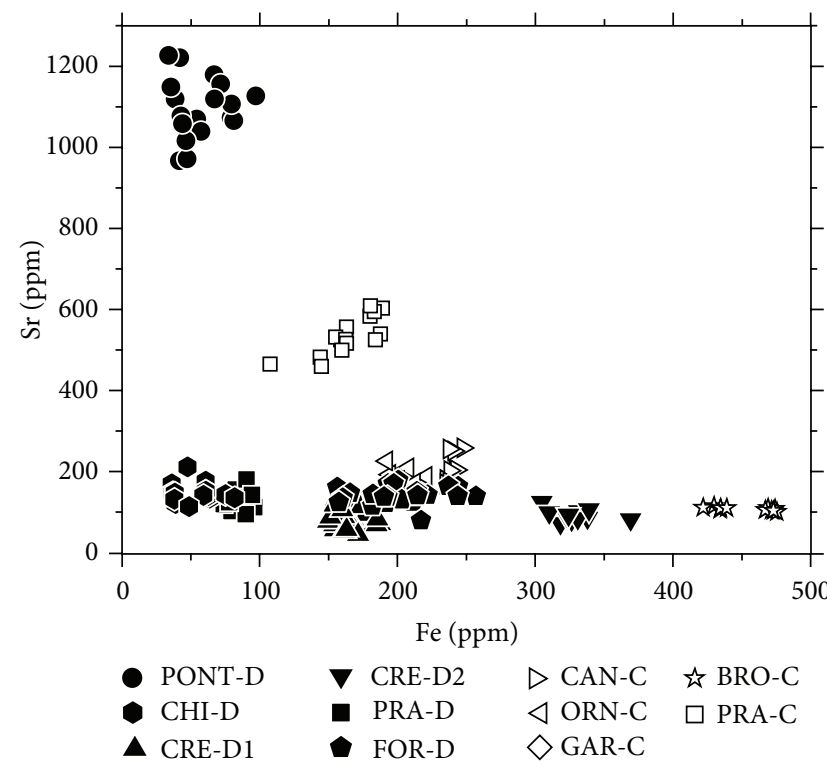

(a)

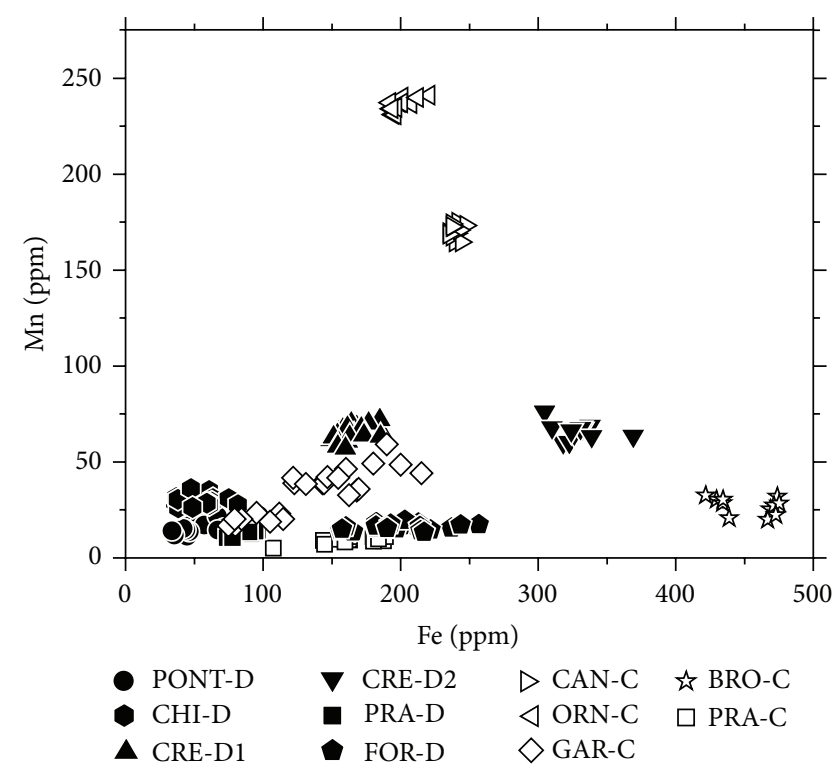

(b)

Figure 2: Two elements scatter plot (a): Fe versus Sr; (b) Fe versus Mn.

TABLE 3: Correlation matrix of the whole set of variables.

\begin{tabular}{lcccccccc}
\hline & $\delta^{13} \mathrm{C}$ & $\mathrm{MGS}$ & $\mathrm{AGS}$ & $\delta^{18} \mathrm{O}$ & $\mathrm{Ca}$ & $\mathrm{Fe}$ & $\mathrm{Sr}$ & -0.107 \\
\hline$\delta^{13} \mathrm{C}$ & 1.000 & -0.436 & -0.453 & 0.575 & 0.165 & -0.369 & -0.152 \\
$\mathrm{MGS}$ & -0.436 & 1.000 & 0.991 & -0.862 & 0.589 & 0.404 & -0.032 \\
$\mathrm{AGS}$ & -0.453 & 0.991 & 1.000 & -0.890 & 0.562 & 0.360 & 0.066 \\
$\delta^{18} \mathrm{O}$ & 0.575 & -0.862 & -0.890 & 1.000 & -0.292 & -0.122 & -0.235 & -0.665 \\
$\mathrm{Ca}$ & 0.165 & 0.589 & 0.562 & -0.292 & 1.000 & 0.335 & -0.098 & 0.384 \\
$\mathrm{Fe}$ & -0.369 & 0.404 & 0.360 & -0.122 & 0.335 & 1.000 & -0.418 & 0.224 \\
$\mathrm{Sr}$ & -0.107 & -0.032 & 0.066 & -0.235 & -0.098 & -0.418 & 1.000 & -0.236 \\
$\mathrm{Mn}$ & -0.152 & 0.797 & 0.743 & -0.665 & 0.384 & 0.224 & -0.236 & 1.000 \\
\hline
\end{tabular}

However, from the observation of diagrams in Figure 2, the random scattering of the points representative of calcite (empty symbols) and dolomite (black symbols) leads to the conclusion that the concentration of trace elements, in each variety of marble, does not depend primarily on the type of carbonate mineral phase.

Despite some experimental field values of marble varieties plot in well distinguishable fields (e.g. PONT-D, PRA-C, CRE-D2, CAN-C, and BRO-C), in other cases the data points span similar regions in the variable space, without being clearly grouped. Therefore, the discrimination based on scatter-plot diagrams appears to be problematic.

For this reason, in order to obtain more quantitative information, discriminant analyses of the data, using the complete sets of variables, were performed. In this way percentages of correct reassignment may be obtained and the discriminating capability of the proposed technique may be assessed.

5.2. Multivariate Analysis. The whole set of our experimental results can be summarized by a data matrix, which contains the values of 8 variables (MGS, AGS, $\delta^{18} \mathrm{O}, \delta^{13} \mathrm{C}, \mathrm{CaO}, \mathrm{Fe}$, $\mathrm{Mn}$, and $\mathrm{Sr}$ ) for the 178 data points, categorized into 11 clusters (ORN-C, CAN-C, BRO-C, GAR-C, PONT-D, FOR-D, CHID, CRE-D1, CRE-D2, PRA-C and PRA-D).

As the first step, all observations and all eight continuous variables of Tables 1 and 2 were used in the PCA. We obtained a correlation matrix (Table 3) where MGS and AGS are greatly related to each other (0.99), both strongly inversely correlated with $\delta^{18} \mathrm{O}(-0.86$ and -0.89 , resp.) and directly correlated with $\mathrm{Mn}(0.80$ and 0.74 , resp. $) . \delta^{13} \mathrm{C}$ is also moderately correlated with $\delta^{18} \mathrm{O}(0.58)$.

Therefore, a lower number of variables might be enough discriminative for our purpose. So an input matrix with a number of variables ranging from 3 to $5\left(\mathrm{Fe}, \mathrm{Mn}, \mathrm{Sr}, \delta^{18} \mathrm{O}\right.$, $\mathrm{CaO}$, and/or $\delta^{13} \mathrm{C}$ ) was used: all the PCA diagrams obtained are reported in Figure 3. Tables 4 and 5 are reported all statistical data processing connected to PCA calculation (corresponding to Figures 3(b) and 3(d), resp.), where the correlation matrix with its eigenvalues (in descending order) and extracted eigenvectors (PC1 and PC2 coefficients referring to the first 2 eigenvalues) is reported. 
TABLE 4: Eigenvalues (in descending order) and extracted eigenvectors (PC1 and PC2 coefficients referring to the first 2 eigenvalues are reported in bold) belonging to the correlation matrix: PCA performed on 4 variables ( $\mathrm{CaO}, \mathrm{Fe}, \mathrm{Sr}$, and $\mathrm{Mn}$ ).

(a)

\begin{tabular}{lcccc}
\hline \multicolumn{5}{c}{ Correlation Matrix } \\
& $\mathrm{Sr}$ & $\mathrm{Fe}$ & $\mathrm{Mn}$ & $\mathrm{CaO}$ \\
\hline $\mathrm{Sr}$ & 1.000 & -0.418 & -0.236 & -0.098 \\
$\mathrm{Fe}$ & -0.418 & 1.000 & 0.224 & 0.335 \\
$\mathrm{Mn}$ & -0.236 & 0.224 & 1.000 & 0.384 \\
$\mathrm{CaO}$ & -0.098 & 0.335 & 0.384 & 1.000 \\
\hline
\end{tabular}

(b)

\begin{tabular}{lccc}
\hline & & Eigenvalue & \\
& Eigenvalue & Variance\% & Cumulative \\
\hline 1 & $\mathbf{1 . 8 5 3}$ & $\mathbf{4 6 . 3 3 \%}$ & $\mathbf{4 6 . 3 3 \%}$ \\
2 & $\mathbf{0 . 9 7 4}$ & $\mathbf{2 4 . 3 6 \%}$ & $\mathbf{7 0 . 6 9 \%}$ \\
3 & 0.709 & $17.72 \%$ & $88.42 \%$ \\
4 & 0.463 & $11.58 \%$ & $100.00 \%$ \\
\hline
\end{tabular}

(c)

\begin{tabular}{lcccc}
\hline \multicolumn{5}{c}{ Eigenvector } \\
Coef. & $\mathrm{Sr}$ & $\mathrm{Fe}$ & $\mathrm{Mn}$ & $\mathrm{CaO}$ \\
\hline PC1 & -0.460 & 0.549 & 0.493 & 0.491 \\
PC2 & 0.647 & -0.320 & 0.408 & 0.558 \\
\hline
\end{tabular}

About correlation, matrix it is interesting to note the highest inverse correlation $(-0.665)$ between $\delta^{18} \mathrm{O}$ and $\mathrm{Mn}$ in Table 5 and medium correlation of $\mathrm{Sr}$ versus $\mathrm{Fe}(-0.418), \mathrm{CaO}$ versus $\mathrm{Mn}(0.384)$, and $\mathrm{CaO}$ versus $\mathrm{Fe}(0.335)$ in Tables 4 and 5. It is also notable that, by using only the first two principal components (PC1 and PC2), in both cases of Tables 4 and 5, we extract a cumulative percentage of about $70 \%$. Element vectors of Figure 3 refer to PC1 and PC2 coefficient of Tables 4 and 5 (right and top scale) while single scatter points refer to PC1 and PC2 score (bottom and left scale) corresponding to the linear combination of original variable and principal component coefficients.

In Figure 3(a), the scoreplots obtained using trace elements ( $\mathrm{Mn}, \mathrm{Fe}$, and $\mathrm{Sr}$ ) show that only the marble type which is also discriminated in the scatter plots of Figure 2 (ORN-C, CAN-C, CRE-D2, BRO-C, and PONT-D) can be easily distinguished, while partial overlaps remain for the other marble varieties. In Figure 3(b), obtained using trace elements and $\mathrm{CaO}$ concentration, a good separation between most marble types, especially between calcite and dolomite marbles, occurs. Only PRA-D and CHI-D marbles are still overlapping. Figure 3(c), where $\delta^{18} \mathrm{O}, \delta^{13} \mathrm{C}, \mathrm{Mn}, \mathrm{Fe}$, and $\mathrm{Sr}$ variables are used, shows that CAN-C and ORN-C partially overlap while a severe overlap occurs between CRE-D2 and FOR-D and between CHI-D and PRA-D, respectively. Finally, in Figure 3(d), where $\delta^{18} \mathrm{O}, \mathrm{CaO}, \mathrm{Mn}, \mathrm{Fe}, \mathrm{Sr}$ variables are used, the dolomite marbles are well separated from the calcite types. Moreover, the different varieties are well distinguished except GAR-C marble which partially overlaps FOR-D field.
TABLE 5: Eigenvalues (in descending order) and extracted eigenvectors ( $\mathrm{PC} 1$ and $\mathrm{PC} 2$ coefficients referring to the first 2 eigenvalues are reported in bold) belonging to the correlation matrix: PCA performed on 5 variables $\left(\delta^{18} \mathrm{O}, \mathrm{CaO}, \mathrm{Fe}, \mathrm{Sr}\right.$, and $\left.\mathrm{Mn}\right)$.

(a)

\begin{tabular}{lccccc}
\hline \multicolumn{5}{c}{ Correlation Matrix } \\
& $\delta^{18} \mathrm{O}$ & $\mathrm{CaO}$ & $\mathrm{Fe}$ & $\mathrm{Sr}$ & $\mathrm{Mn}$ \\
\hline$\delta^{18} \mathrm{O}$ & 1.000 & -0.292 & -0.122 & -0.235 & -0.665 \\
$\mathrm{CaO}$ & -0.292 & 1.000 & 0.335 & -0.098 & 0.384 \\
$\mathrm{Fe}$ & -0.122 & 0.335 & 1.000 & -0.418 & 0.224 \\
$\mathrm{Sr}$ & -0.235 & -0.098 & -0.418 & 1.000 & -0.236 \\
$\mathrm{Mn}$ & -0.665 & 0.384 & 0.224 & -0.236 & 1.000 \\
\hline
\end{tabular}

(b)

\begin{tabular}{cccc}
\hline & & $\begin{array}{c}\text { Eigenvalue } \\
\text { Variance\% }\end{array}$ & Cumulative \\
\hline 1 & $\mathbf{2 . 0 9 8}$ & $\mathbf{4 1 . 9 5 \%}$ & $\mathbf{4 1 . 9 5 \%}$ \\
2 & $\mathbf{1 . 4 0 8}$ & $\mathbf{2 8 . 1 6 \%}$ & $\mathbf{7 0 . 1 1 \%}$ \\
3 & 0.747 & $14.94 \%$ & $85.05 \%$ \\
4 & 0.570 & $11.41 \%$ & $96.46 \%$ \\
5 & 0.177 & $3.54 \%$ & $100.00 \%$ \\
\hline
\end{tabular}

(c)

\begin{tabular}{lccccc}
\hline \multicolumn{5}{c}{ Eigenvector } \\
Coef. & $\delta^{18} \mathrm{O}$ & $\mathrm{CaO}$ & $\mathrm{Fe}$ & $\mathrm{Sr}$ & $\mathrm{Mn}$ \\
\hline PC1 & -0.477 & 0.473 & 0.400 & -0.218 & 0.584 \\
PC2 & 0.521 & 0.019 & 0.473 & -0.69 & -0.172 \\
\hline
\end{tabular}

In Figures 3(b) and 3(d) there is a better separation, but not fully reached, between the 11 classes of the studied marble. For this reason HCA analysis was performed, using the variable selections of Figures 3(b) and 3(d).

Using the HCA method, the dendrograms of Figures 4 and 5 are obtained: the abscissa corresponds to the progressive observation number (from 1 to 178) and the ordinate reports the normalized square Euclidean distance between observations where the horizontal lines indicate the mergence of two clusters. Figure 4 was performed using 4 variables ( $\mathrm{CaO}, \mathrm{Mn}, \mathrm{Fe}$, and $\mathrm{Sr}$ ) and Figure 5 using 5 variables $\left(\delta^{18} \mathrm{O}, \mathrm{CaO}, \mathrm{Mn}, \mathrm{Fe}\right.$, and $\left.\mathrm{Sr}\right)$. In both figures, the main discriminative parameter resulted in the $\mathrm{CaO}$ contents, which allowed separating the marble variety according to their main forming mineral (dolomite at the left branch and calcite at the right branch). In Figure 4, ten cluster are clearly separate, while in, Figure 5, all eleven marble classes are discriminated.

Looking in more details of the calcitic branch (right side of Figure 4), CAN-C and ORN-C are the first to merge (distance of 0.088 ) being marbles coming from the same geological unit but outcropping in a different quarry district. PRA-C and GAR-C merge at a larger distance (0.137). Finally, Brossasco marble, which has high AGS and MGS, comparable to Ornavasso/Candoglia marble, results, however, chemically more similar to Prali and Garessio (distance $=0.546$ ). All calcitic marbles become a single cluster at distance of 0.713 . 


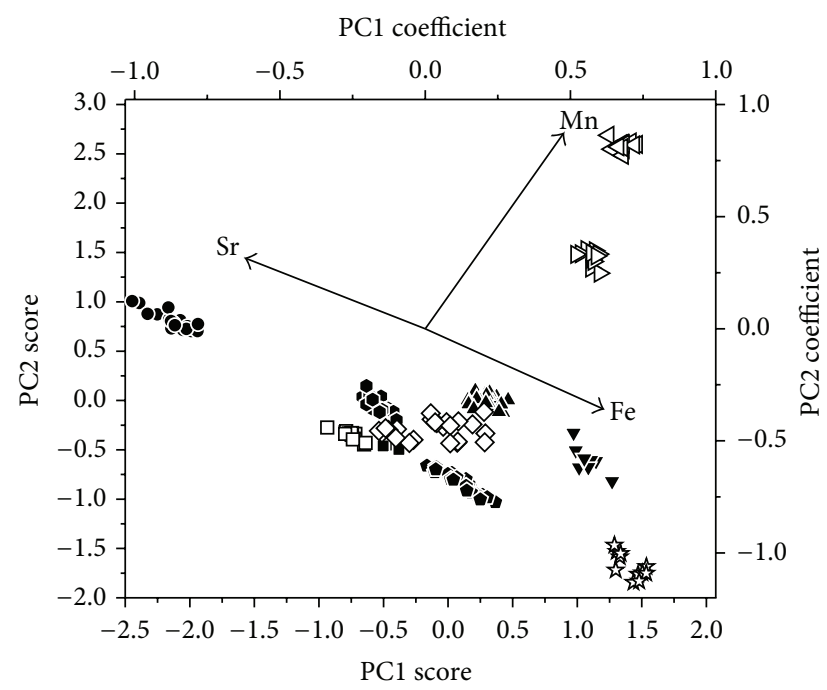

(a)

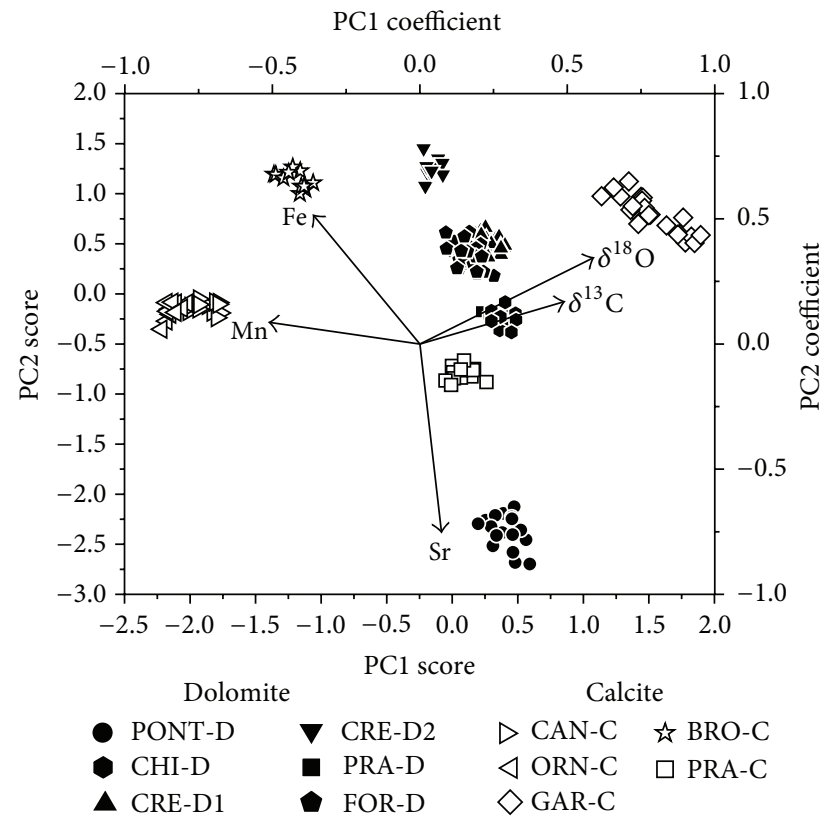

(c)

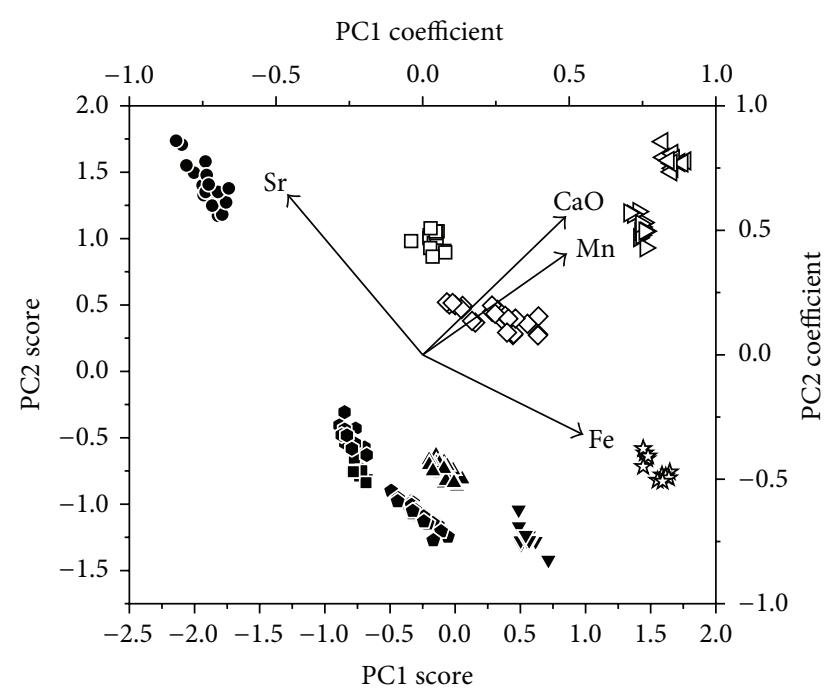

(b)

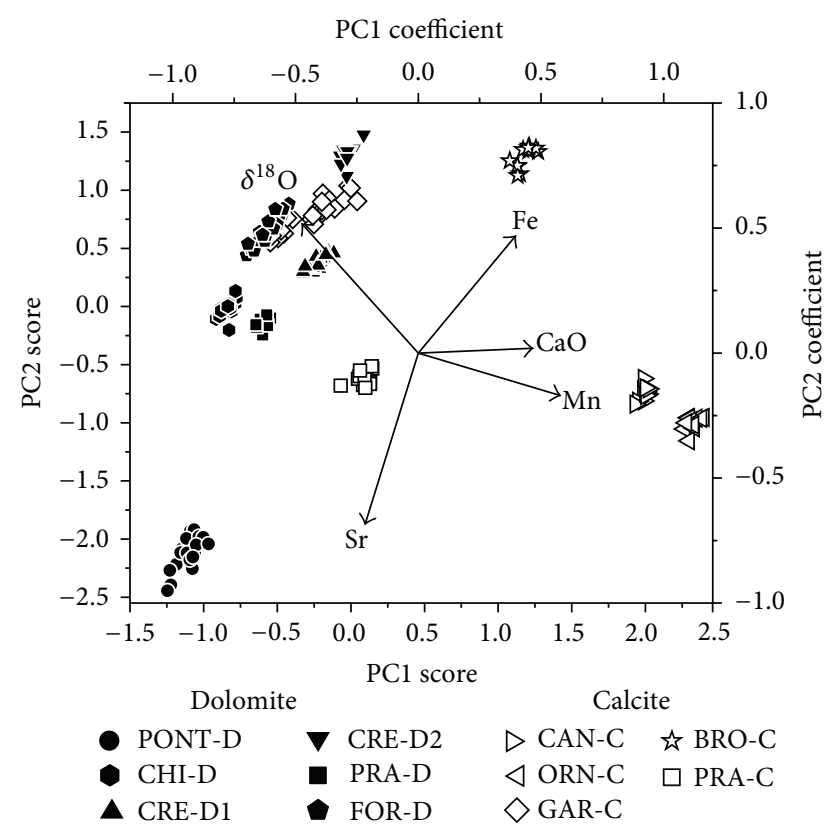

(d)

Figure 3: PCA performed on (a) 3 variables (Mn, Fe, and Sr); (b) 4 variables (CaO, Mn, Fe, and Sr); (c) 5 variables $\left(\delta^{18} \mathrm{O}, \delta^{13} \mathrm{C}, \mathrm{Mn}, \mathrm{Fe}\right.$, and $\mathrm{Sr})$; (d) 5 variables $\left(\delta^{18} \mathrm{O}, \mathrm{CaO}, \mathrm{Mn}, \mathrm{Fe}\right.$, and $\mathrm{Sr}$ ). Single scatter points refer to bottom and left scale (PC scores); element vectors refer to right and top scale (PC coefficients).

In regard to the dolomitic branch (left side of Figure 4), PRA-D and CHI-D constitute a single cluster as they merge at the minimum distance (0.013). CRE-D1 and FOR-D combine at 0.055 , and CRE-D2 merges with the previous cited marbles only at 0.222 . Therefore, the two varieties of Crevola marble are significantly far and dissimilar. Finally, PONT-D marble differs from all the others and merge, forming a single dolomitic marble cluster, at 0.806 . This behavior of Pont Canavese marble is mostly due to the significantly higher $\mathrm{Sr}$ concentration as well shown also in scatter plot of Figure 2(a) and PCA plots of Figure 3.
If $\delta^{18} \mathrm{O}$ variable is added (Figure 5), PRA-D and CHI-D merge at a larger distance (0.062) with respect to Figure 4 $(d=0.013)$, resulting easier to discriminate. Therefore, HCA with 5 variables allowed separating all 11 clusters. Moreover, in both dolomitic and calcitic branch, a generally significant increase in the distance due to the wide difference in $\delta^{18} \mathrm{O}$ values is shown (Table 1). However, no changes in clusters occur and the order of hierarchy remains the same. In Table 6, the final centres for each cluster after HCA analysis using four (A) and five (B) variables are reported. Proper grouping observations are obtained for 10 and 11 clusters, respectively 
TABLE 6: Final cluster centers after HCA analysis using four (A) and five (B) variables: proper grouping observations are obtained for 10 and 11 clusters (CL), respectively (Figures 4 and 5).

\begin{tabular}{|c|c|c|c|c|c|c|c|c|c|c|c|c|c|c|}
\hline \multicolumn{15}{|c|}{ Final Cluster Centers } \\
\hline \multirow{2}{*}{\multicolumn{7}{|c|}{$\begin{array}{c}\text { A } \\
\text { variables }\end{array}$}} & \multicolumn{8}{|c|}{ B } \\
\hline & & & & & & & & \multirow[b]{2}{*}{ Marble } & \multirow[b]{2}{*}{$\#$} & \multicolumn{2}{|c|}{5 variables } & \multirow[b]{2}{*}{$\mathrm{Sr}$} & \multirow[b]{2}{*}{$\mathrm{Mn}$} & \\
\hline $\mathrm{CL}$ & Marble & $\#$ & $\mathrm{Ca}$ & $\mathrm{Fe}$ & $\mathrm{Sr}$ & $\mathrm{Mn}$ & $\mathrm{CL}$ & & & $\mathrm{Ca}$ & $\mathrm{Fe}$ & & & $\delta^{18} \mathrm{O}$ \\
\hline 1 & PONT-D & 19 & 0.039 & 0.000 & 1.000 & 0.030 & 1 & PONT-D & 19 & 0.039 & 0.006 & 1.000 & 0.030 & 0.463 \\
\hline 2 & CRE-D1 & 25 & 0.043 & 0.274 & 0.000 & 0.243 & 2 & CRE-D1 & 25 & 0.043 & 0.279 & 0.000 & 0.243 & 0.648 \\
\hline 3 & FOR-D & 25 & 0.000 & 0.364 & 0.054 & 0.031 & 3 & FOR-D & 25 & 0.000 & 0.368 & 0.054 & 0.031 & 0.741 \\
\hline \multirow{2}{*}{4} & \multirow{2}{*}{ PRA-D/CHI-D } & \multirow{2}{*}{25} & \multirow{2}{*}{0.028} & \multirow{2}{*}{0.027} & \multirow{2}{*}{0.054} & \multirow{2}{*}{0.061} & 4 & PRA-D & 10 & 0.044 & 0.082 & 0.043 & 0.019 & 0.481 \\
\hline & & & & & & & 5 & CHI-D & 15 & 0.017 & 0.000 & 0.061 & 0.089 & 0.704 \\
\hline 5 & CRE-D2 & 11 & 0.016 & 0.685 & 0.007 & 0.250 & 6 & CRE-D2 & 11 & 0.016 & 0.687 & 0.007 & 0.250 & 0.861 \\
\hline 6 & PRA-C & 15 & 0.934 & 0.271 & 0.444 & 0.000 & 7 & PRA-C & 15 & 0.934 & 0.276 & 0.444 & 0.000 & 0.454 \\
\hline 7 & GAR-C & 23 & 1.000 & 0.203 & 0.060 & 0.111 & 8 & GAR-C & 23 & 1.000 & 0.208 & 0.060 & 0.111 & 1.000 \\
\hline 8 & BRO-C & 11 & 0.961 & 1.000 & 0.021 & 0.078 & 9 & BRO-C & 11 & 0.961 & 1.000 & 0.021 & 0.078 & 0.463 \\
\hline 9 & CAN-C & 12 & 0.999 & 0.461 & 0.113 & 0.709 & 10 & CAN-C & 12 & 0.999 & 0.465 & 0.113 & 0.709 & 0.009 \\
\hline 10 & ORN-C & 12 & 0.955 & 0.363 & 0.089 & 1.000 & 11 & ORN-C & 12 & 0.955 & 0.367 & 0.089 & 1.000 & 0.000 \\
\hline
\end{tabular}

All variable columns are normalized in the range $0-1$. \# = number of investigated carbonate grains.

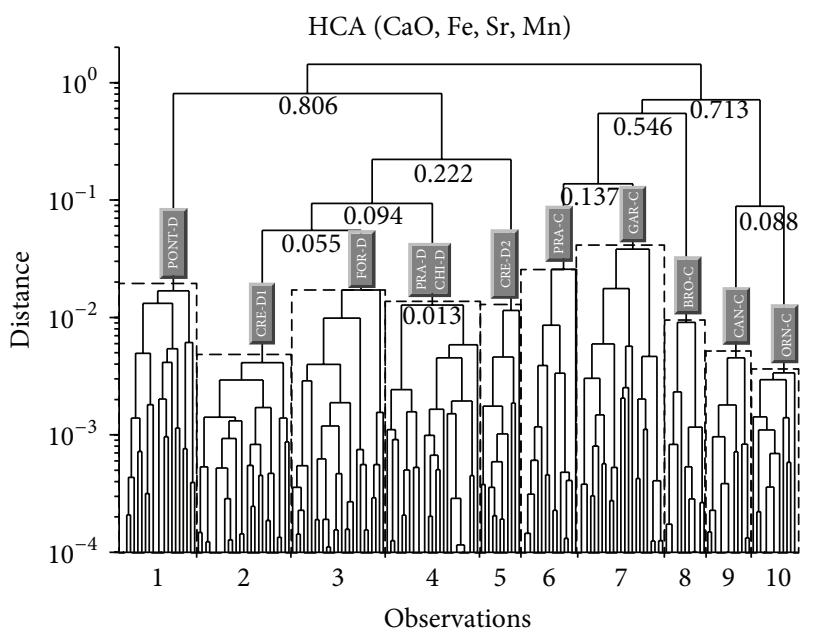

FIGURE 4: Ward's dendrogram of hierarchical cluster analysis using 4 variables $(\mathrm{CaO}, \mathrm{Mn}, \mathrm{Fe}$, and $\mathrm{Sr})$. The distance is visualised as logarithmic scale.

(Figures 4 and 5). All variable columns are normalized in the range 0-1. The distance between the cluster centers always improves passing from 4 to 5 variables: the greatest increase (difference $=0.735$ ) is between CAN-C and CRE-D2.

HCA method realizes, in the case of 4 variables, $86 \%$ of correct clustering observations since cluster number 4 of Table 6(A) (PRA-D/CHI-D), containing 25 observations (corresponding to $14 \%$ of the total), can be considered not properly assigned (Figure 4 and Table 6(A)). In the case of 5 variables, all observations can be considered correctly assigned (Figure 5 and Table 6(B)).

Even if the distance between PRA-D and CHI-D cluster centers remains low $(0.062$ in Table 6(B)), it, however, allows distinguishing PRA-D and CHI-D and the separation between the different marble types appears complete.

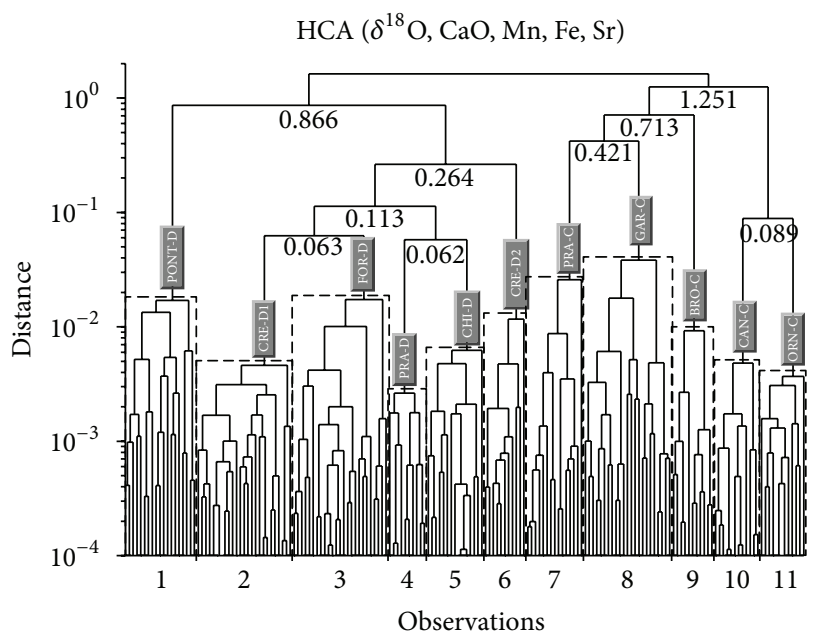

Figure 5: Ward's dendrogram of Hierarchical Cluster Analysis using 5 variables $\left(\delta^{18} \mathrm{O}, \mathrm{CaO}, \mathrm{Mn}, \mathrm{Fe}\right.$, and $\left.\mathrm{Sr}\right)$. The distance is visualised as logarithmic scale.

\section{Conclusions}

In this paper, the petrographical, minerochemical, and C-O isotopic data of white marbles from Western Alps, previously described by means of classical techniques as optical and electron microscope, electron microprobe, and stable isotope analysis [20], have been integrated with trace elements analysis on the carbonate mineral phases (calcite and dolomite) performed by means of a $\mu$-XRF instrument. The results presented above for the multimethod discrimination of the white marbles from Western Alps are certainly encouraging.

The method here proposed seems capable of allowing discrimination among the Western Alps white marbles with acceptable confidence. In particular, the PCA method, using two principal components, based on a maximum of 5 
variables, extracts about $70 \%$ of the available variance. HCA method properly assigns $86 \%$ of observations to ten clusters using $\mathrm{CaO}, \mathrm{Mn}, \mathrm{Fe}$, and $\mathrm{Sr}$ variables and the total observations to proper eleven clusters using $\delta^{18} \mathrm{O}, \mathrm{CaO}, \mathrm{Mn}, \mathrm{Fe}$, and $\mathrm{Sr}$ variables.

The possibility of making $\mu$-XRF trace element analyses on white marbles provided the opportunity of improving previous archaeometric approaches and will allow performing quantitative analysis either on archaeological finds smaller than $\approx 150 \times 150 \times 70 \mathrm{~mm}$ or on small fragments (at least $100 \times 100 \times 300 \mu \mathrm{m})$ by nondestructive analytical procedures. Obviously, the data presented are still few and should be implemented with other measures to make the proposed procedure more significant. Therefore, the proposed discriminative approach, mostly based on trace elements in the carbonate phase and on the $\delta^{18} \mathrm{O}$ isotopic signature, will be applied to white marbles from the Mediterranean area in order to obtain a complete characterisation of such important natural stones, used from antiquity up to now for cultural heritage.

\section{Conflict of Interests}

The authors declare that there is no conflict of interests regarding the publication of this paper.

\section{Acknowledgments}

The $\mu$-XRF measures have been obtained with the equipment acquired by the Interdepartmental Center "G. Scansetti" for Studies on Asbestos and Other Toxic Particulates with a grant from Compagnia di San Paolo, Torino, Italy. Special thanks are due to B. Fubini and R. Compagnoni (Center "G. Scansetti" UNITO) for encouragement and for providing $\mu$ XRF. Financial support by the Italian Ministry of Instruction, University and Research and by the National Council of Research.

\section{References}

[1] J. Zöldföldi, B. Szekely, and Ch. Franzen, "Interdisciplinary data base of historically relevant marble material for archaeometric, art historian and restoration use," in Natursteinsanierung Stuttgart 2004, Neue Natursteinsanierungsergebnisse und Messtechnische Erfassungen, G. Grassegger-Schön and G. Patitz, Eds., pp. 79-86, Siegl, Munchen, Germany, 2004.

[2] H. Craig and V. Craig, "Greek marbles: determination of provenance by isotopic analysis," Science, vol. 176, no. 4030, pp. 401403, 1972.

[3] N. Herz, "The oxygen and carbon isotopic data base for classical marble," in ASMOSIA I: Classical Marble: Geochemistry, Technology, Trade, N. Herz and M. Waelkens, Eds., pp. 305-314, Kluwer Academic, Dodrecht, The Netherlands, 1988.

[4] C. Gorgoni, L. Lazzarini, P. Pallante, and B. Turi, "An updated and detailed mineropetrographic and $\mathrm{C}-\mathrm{O}$ stable isotopic reference database for the main Mediterranean marbles used in antiquity," in ASMOSIA V: Interdisciplinary Studies on Ancient Stone, J. J. Hermann, N. Herz, and R. Newton, Eds., pp. 115-131, Archetype Publications, London, UK, 2002.
[5] D. Attanasio, M. Brilli, and N. Ogle, The Isotopic Signature of Classical Marbles, L'Erma di Bretschneider, Roma, Italy, 2006.

[6] V. Barbin, K. Ramseyer, D. Decrouez, S. V. Burns, and J. L. Mayer, "Cathodoluminescence of white marbles: an overview," Archaeometry, vol. 43, pp. 175-183, 1992.

[7] J. J. Herrmann Jr. and V. Barbin, “The exportation of marble from the Aliki Quarries on Thasos: cathodoluminescence of samples from Turkey and Italy," The American Journal of Archaeology, vol. 97, pp. 91-103, 1993.

[8] E. Mello, D. Monna, and M. Oddone, "Discriminating sources of mediterranean marbles: a pattern recognition approach," Archaeometry, vol. 30, pp. 102-108, 1988.

[9] M. Unterwurzacher, J. Polleres, and P. Mirwald, "Provenance study of marble artefacts from the Roman burial area of Faschendorf (Carinthia, Austria)," Archaeometry, vol. 47, no. 2, pp. 265-273, 2005.

[10] V. Perdikatsis, K. Kritsotakis, T. Markopoulos, and K. Laskaridis, "Discrimination of Greek marbles by trace-, isotope- and mineralogical analysis," in Fracture and Failure of Natural Building Stones, S. K. Kourkoulis, Ed., pp. 497-515, Springer, Dordrecht, Germany, 2006.

[11] D. Attanasio, Ancient White Marbles: Analysis and Identification by Paramagnetic Resonance Spectroscopy, L'Erma di Bretschneider, Roma, Italy, 2003.

[12] N. Herz, D. G. Mose, and D. B. Wenner, "A possible discriminant for classical marble provenance," Geological Society of America Abstracts With Programs, vol. 14, p. 514, 1982.

[13] M. Brilli, G. Cavazzini, and B. Turi, "New data of 87Sr/86Sr ratio in classical marble: an initial database for marble provenance determination," Journal of Archaeological Science, vol. 32, no. 10, pp. 1543-1551, 2005.

[14] D. Taelman, M. Elburg, L. Lopes, and P. de Paepe, "Quarrying the Estremoz marbles (portugal): archeological, petrographical and geochemical characterization," ASMOSIA Abstracts, vol. 2012, pp. 235-236, 2012.

[15] L. Lazzarini, G. Moschini, and B. M. Stievano, "A contribution to the identification of italian, greek and anatolian marbles through a petrological study and the evaluation of $\mathrm{Ca} / \mathrm{Sr}$ ratio," Archaeometry, vol. 22, no. 2, pp. 173-182, 1980.

[16] L. Rybach and H. U. Nissen, "Neutron activation of Mn and $\mathrm{Na}$ traces in marbles worked by the ancient Greeks," in Proceedings of the Radiochemical Methods of Analysis, pp. 105117, Salisburgo, Austria, 1965.

[17] M. Oddone, S. Meloni, and E. Mello, "Provenance studies of the white marble of the cathedral of Como by neutron activation analysis and data reduction," Journal of Radioanalytical and Nuclear Chemistry, vol. 90, no. 2, pp. 373-381, 1985.

[18] A. P. Grimanis and M. Vassilaki-Grimani, "Provenance studies of greek marbles by instrumental neutron activation analysis," in Classical Marble: Geochemistry, Technology, Trade, N. Herz and M. Wealkens, Eds., vol. 153 of NATO ASI Series, pp. 275281, Kluwer Academic, 1988.

[19] L. Moens, P. Roos, J. de Rudder, and J. Hoste, "Archaeometry," in Proceedings of the 25th International Symposium on Archaeometry, Y. Maniatis, Ed., Elsevier, Amsterdam, The Netherlands, 1989.

[20] A. Borghi, G. Vaggelli, C. Marcon, and L. Fiora, "The piedmont white marbles used in antiquity: an archaeometric distinction inferred by a minero-petrographic and c-o stable isotope study," Archaeometry, vol. 51, no. 6, pp. 913-931, 2009. 
[21] K. J. Matthews, "The establishment of a data base of neutron activation analyses of white marble," Archaeometry, vol. 39, no. 2, pp. 321-332, 1997.

[22] D. Attanasio, G. Armiento, M. Brilli, M. C. Emanuele, R. Platania, and B. Turi, "Multi-method marble provenance determinations: the Carrara marbles as a case study for the combined use of isotopic, electron spin resonance and petrographic data," Archaeometry, vol. 42, no. 2, pp. 257-272, 2000.

[23] D. Attanasio, R. Platania, and P. Rocchi, "The marble of the David of Michelangelo: a multi-method analysis of provenance," Journal of Archaeological Science, vol. 32, no. 9, pp. 1369-1377, 2005.

[24] K. Polikreti and Y. Maniatis, "A new methodology for the provenance of marble based on EPR spectroscopy," Archaeometry, vol. 44, no. 1, pp. 1-21, 2002.

[25] K. Polikreti, Y. Maniatis, Y. Bassiakos, N. Kourou, and V. Karageorghis, "Provenance of archaeological limestone with EPR spectroscopy: the case of the Cypriote-type statuettes," Journal of Archaeological Science, vol. 31, no. 7, pp. 1015-1028, 2004.

[26] S. Capedri and G. Venturelli, "Accessory minerals as tracers in the provenancing of archaeological marbles, used in combination with isotopic and petrographic data," Archaeometry, vol. 46, no. 4, pp. 517-536, 2004.

[27] A. Ebert, E. Gnos, K. Ramseyer et al., "Provenance of marbles from Naxos based on microstructural and geochemical characterization," Archaeometry, vol. 52, no. 2, pp. 209-228, 2010.

[28] G. Vaggelli and R. Cossio, " $\mu$-XRF analysis of glasses: aA nondestructive utility for cultural heritage applications," Analyst, vol. 137, no. 3, pp. 662-667, 2012.

[29] M. Serra, A. Borghi, L. M. Gallo, R. Hovoric, and G. Vaggelli, "Petrographic features, genesis and provenance of Pietra Paesina collections of the Regional Museum of Natural Sciences of Turin, Italy," Periodico di Mineralogia, no. 95-111, 2010.

[30] M. Serra, A. Borghi, R. Cabella, L. M. Gallo, and G. Vaggelli, "Micro-XRF trace element quantification in calcite: a contribution to white marble provenance determination," Microscopy \& Microanalysis, vol. 17, supplement S2, pp. 1808-1809, 2011.

[31] G. V. Dal Piaz, "The Austroalpine-Piedmont nappe stack and the puzzle of Alpine Tethys," Memorie di Scienze Geologiche, vol. 51, no. 1, pp. 155-176, 1999.

[32] G. Chiari, F. Colombo, R. Compagnoni et al., "Santa Cristina: restoration of a facade by Filippo Juvarra," in Proceedings of the International Congress on Deterioration and Conservation of Stone, pp. 1393-1402, Lisbon, Portugal, June 1992.

[33] H. J. Lucas-Tooth and C. Pyne, "The accurate determination of major constituents by X-ray fluorescent analysis in the Presence of large interelement effects," Advances in X-ray Analysis, vol. 1964, no. 7, pp. 523-541, 1964.

[34] N. Herz and N. E. Dean, "Stable isotopes and archaeological geology: the Carrara marble, northern Italy," Applied Geochemistry, vol. 1, no. 1, pp. 139-151, 1986.

[35] L. Moens, P. Roos, J. de Rudder et al., "White marble from Italy and Turkey: an archaeometric study based on minor-and traceelement analysis and petrography," Journal of Radioanalytical and Nuclear Chemistry, vol. 123, no. 1, pp. 333-348, 1988.

[36] P. Mirti, M. Aceto, L. Appolonia, and G. Bortolaso, "The provenance of white marbles from Roman buildings in the town of Aosta (Italy)," Science and Technology for Cultural Heritage, vol. 6, pp. 43-55, 1997.
[37] P. A. Baker, J. M. Gieskes, and H. Elderfield, "Diagenesis of carbonates in deep-sea sediments-evidence from $\mathrm{Sr} / \mathrm{Ca}$ ratios and interstitial dissolved Sr data," Journal of Sedimentary Petrology, vol. 52, no. 1, pp. 71-82, 1982.

[38] M. J. Malone and P. A. Baker, "Temperature dependence of the strontium distribution coefficient in calcite: an experimental study from $40^{\circ}$ to $200^{\circ}$ and application to natural diagenetic calcites," Journal of Sedimentary Research, vol. 69, no. 1, pp. 216223, 1999.

[39] E. W. M. Heinrich, Microscopic Petrography, McGraw-Hill, New York, NY, USA, 1956.

[40] M. G. Best, Igneous and Metamorphic Petrology, W. H. Freeman, San Francisco, Calif, USA, 1982.

[41] H. Craig, "Isotopic standards for carbon and oxygen and correction factors for mass-spectrometric analysis of carbon dioxide," Geochimica et Cosmochimica Acta, vol. 12, no. 1-2, pp. 133-149, 1957.

[42] J. M. McCrea, "On the isotopic chemistry of carbonates and a paleotemperature scale," The Journal of Chemical Physics, vol. 18, no. 6, pp. 849-857, 1950.

[43] T. W. Schmid and S. M. Bernasconi, "An automated method for 'clumped-isotope' measurements on small carbonate samples," Rapid Communications in Mass Spectrometry, vol. 24, no. 14, pp. 1955-1963, 2010. 

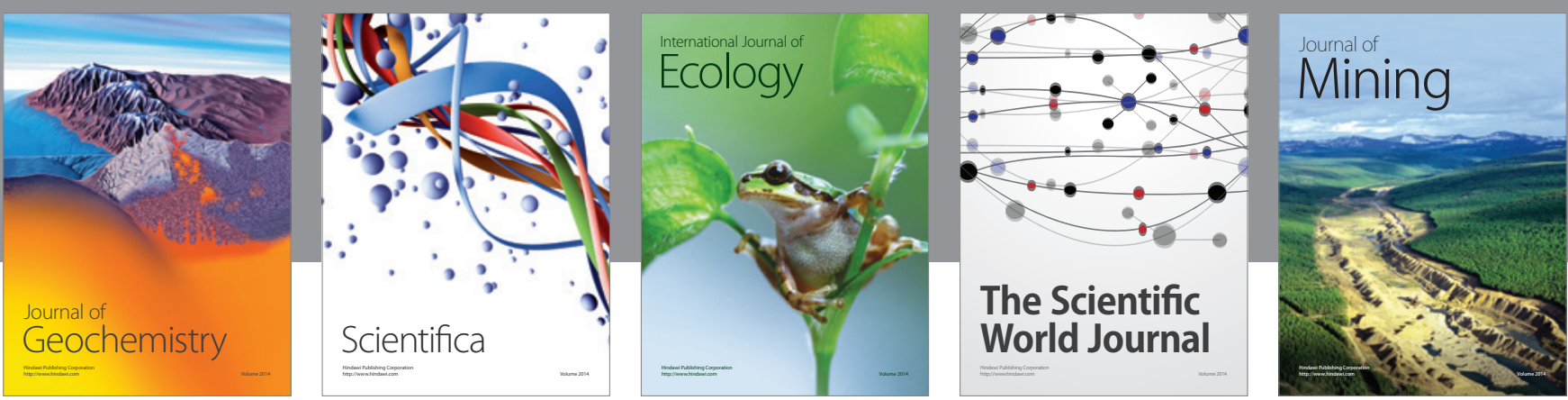

The Scientific World Journal
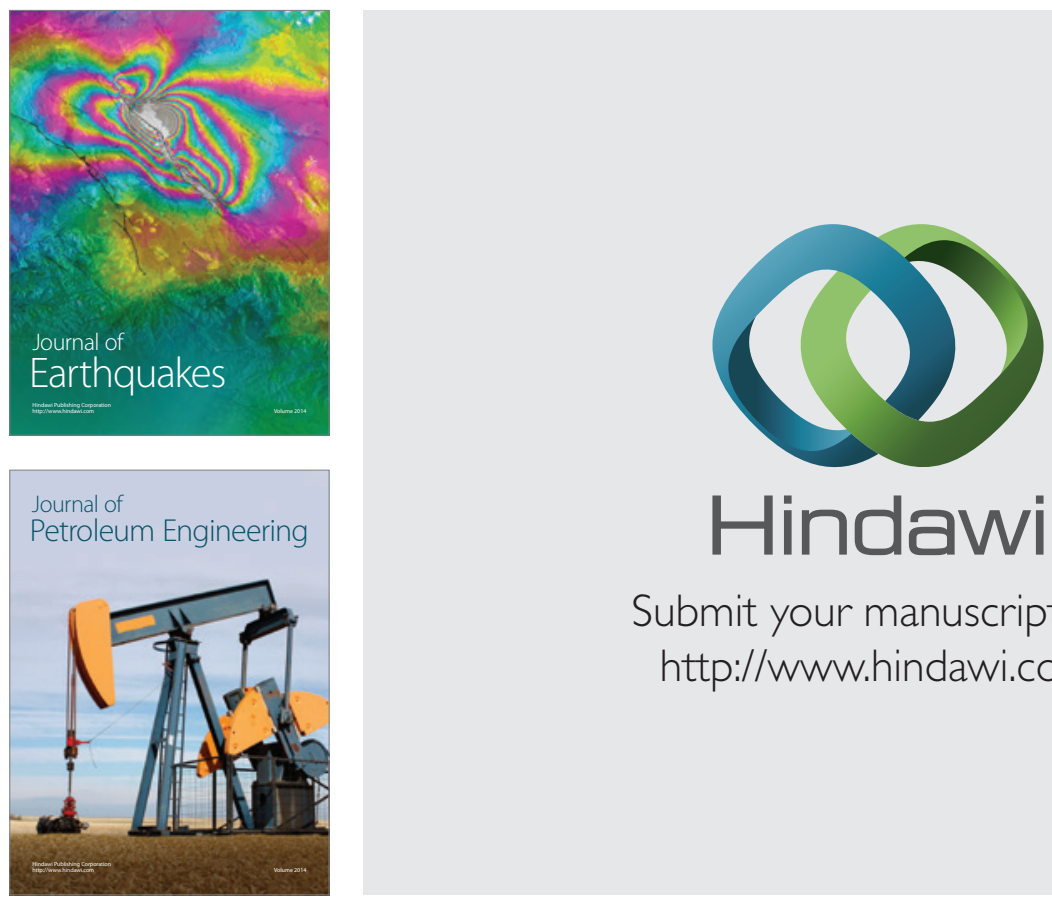

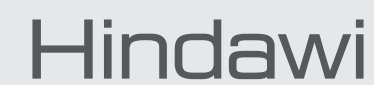

Submit your manuscripts at

http://www.hindawi.com
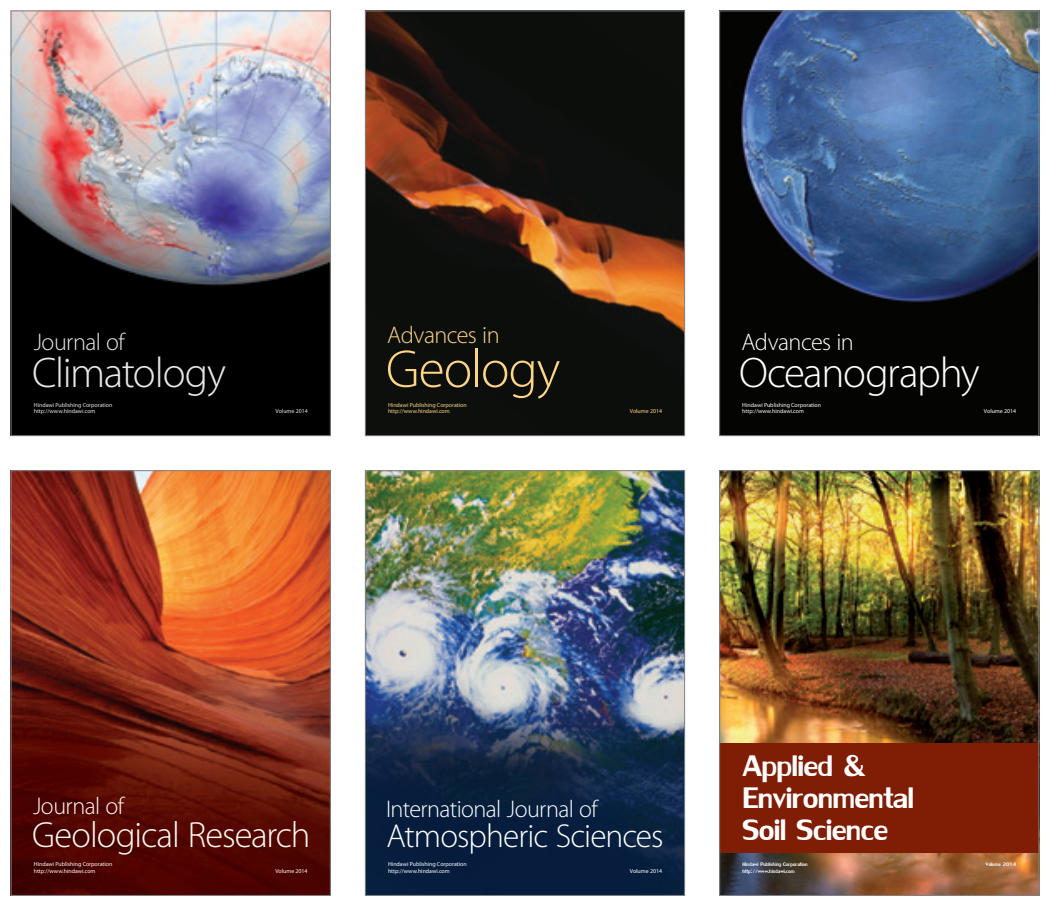
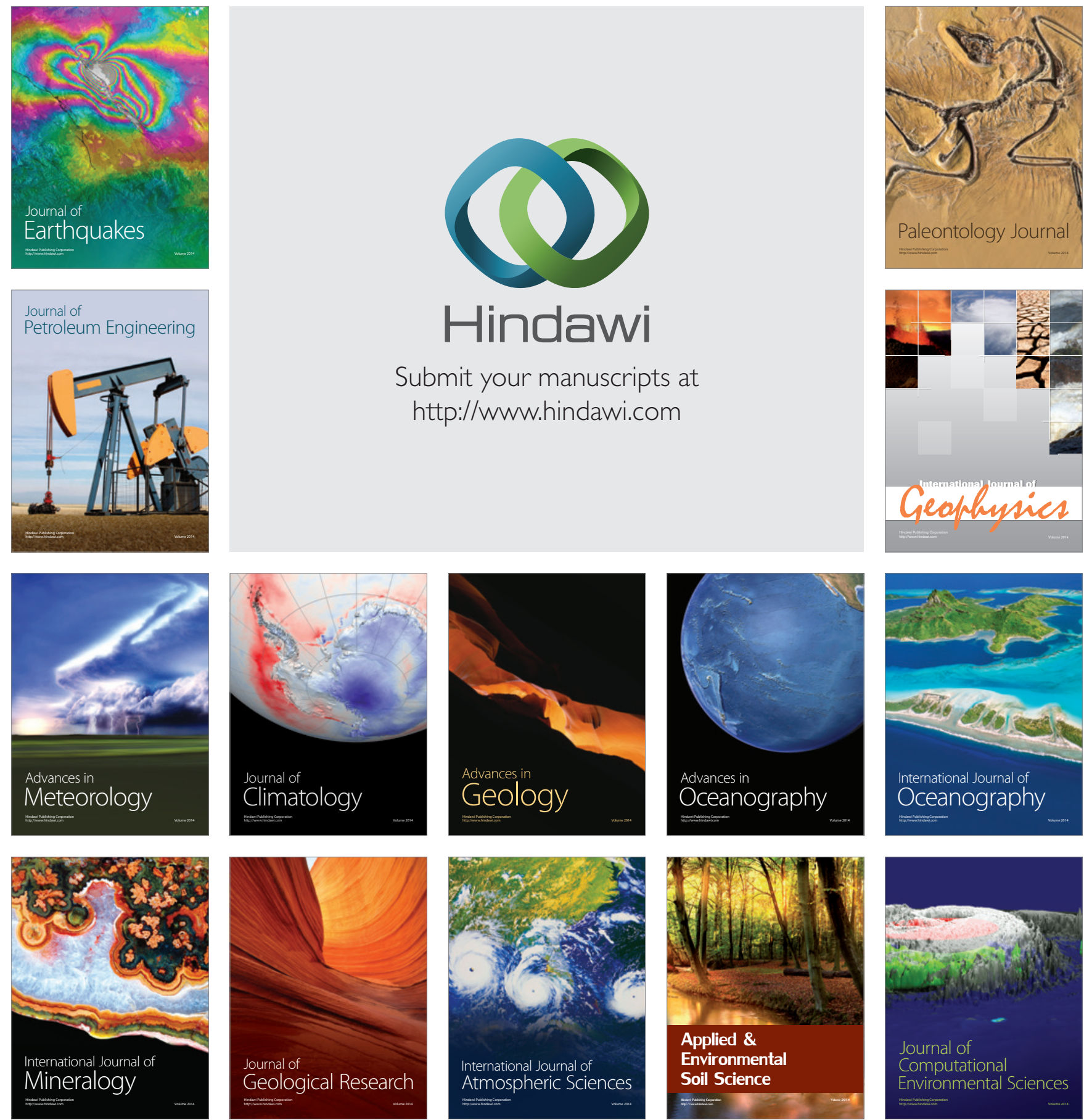